\title{
ПСИХОТЕХНИКА
}

\author{
И.С. Павлов
}

\section{ОБЩЕЧЕЛОВЕЧЕСКАЯ ПРОБЛЕМА «ЦАРЯ В ГОЛОВЕ»}

Аннотация. Предметом исследования является такой актуальный вопрос, как разработка конкретного содержания и технологии подготовки молодых людей к жизни в условиях динамического, изменяющегося, нестабильного мира, сохраняя себя как человека, личность, избегая поджидающих его опасностей, так широко представленных в срере возможного. Нельзя повторять ошибки переходного этапа на другую сочиально-экономическую формацию. Подвёл итоги этого этапа Лауреат Нобелевской премии академии Ж. Алфёров: "Нас бросили в воду, не научив плавать». Надо реально учитывать, что школа - это место не только для образования, но и подготовки молодого человека к жизни в динамическом, бурном развивающем обществе. Основной метод исследования - клинико-психотерапевтический: сравнение и сопоставление полученных данных о девиантном поведении молодых людей с нормативным поведением других. Выявления у последних душевных свойств, интрапсихических механизмов, которые в таких же жизненных ситуациях купируют, исключают проявление девиантных механизмов, которых нет у первых, что особенно важно учитывать в воспитательных целях. Впервые уделено внимание не столько изучению самих девиантных проявлений, что в основном делается в настоящее время, сколько раскрыты и изучены те факторы, которых не хватает молодым людям, у которых наблюдаются девиации в поведении. Рассмотрены интрапсихические механизмы, формированию которых надо уделять в процессе воспитания молодых людей с целью их подготовки к жизни в условиях динамического, изменчивого, нестабильного мира, преобладания в нем в срере возможного негативных тенденций над позитивными под углом зрения системообразующего фактора всего живого - инстинкта самосохранения.

Выводы: 1) Школа - это место не только получения образования, но и, что главное, подготовка к жизни в наше непростое, изменчивое, развивающееся, динамическое время.

2) Важно поддержание системообразующего фрактора всего живого, в том числе у молодых людей - инстинкта самосохранения в его индивидуальных особенностях, т.е. содержание "Я», срормированного в прочессе взаимодействия с окружающим миром.

3) Важно жить не только по принципу “здесь и теперь, сейчас», что даёт полноту переживания настоящего, как жили греки, но и с подтекстом жизни в будущем, прогнозирования своего будущего.

4) Нужно практиковать понятие "свобода", т.е. не односторонне, а учитывая, что в окружающем мире действуют морально-этические, юридические, биологические, общественные, физические, образовательные и иные факторы, закономерности, не принятие во внимание которых не способствует достижению успеха в жизни.

5) Нет в мире абсолютно счастливых людей. Временные трудности, неудачи постигают всех, но их преодоление формирует личность, психическую устойчивость, характер, и умение преодолевать трудности нередко ведёт к успеху в будущей жизни.

6) Жизнь - это калейдоскоп ситуаций, и нельзя трудности в какой-то ситуации воспринимать как жизненный тупик, терять ценность и смысл жизни (двойка на экзамене, неудача в любви и т.п.). В таких ситуациях важно знать, что на эту двойку через какое-то время молодой человек будет смотреть с юмором, неудача в первой любви обучает пониманию, что первая любовь не бывает единственной, необходимо, напротив, проявлять оптимизм, стать прелестнее, привлекательнее, душевнее, проявить безразличие к нему, ведь это все наживное. Опыт показывает, что многие впоследствии рады, что не связали свою жизнь со своей первой любовью. Ведь и Ф. Шаляпина с первого раза не приняли в консерваторию.

7) Жизнь - это главная, высшая ценность (А. Швейцер говорил о “благоговении перед жизнью»), даже учитывая все её трудности - это интересный, творческий, даже азартный процесс.

Ключевые слова: инстинкт, девиантное поведение, самосохранение, эволючионный подход, экзистенция, психотехника, личность, свобода, психотравма, конструирование будущего. 


\title{
Психология и психотехника 2(89) • 2016
}

\begin{abstract}
The article deals with such issues as development and implementation of technology in the program preparing young people for life in our dynamic, changing, unstable world, keeping yourself as a person, the individual, avoiding many dangers waiting for him, so widely represented in the realm of possibility. According to the author, it is very important not to repeat mistakes that are usually made at the transient stage when society adopts another socioeconomic formation. It was well summarized by the Nobel laureate Alferov who said that 'We were thrown into the water but nobody had taught us to swim'. In his research Pavlov emphasizes the fact that school is not only the place where education is provided, it is also the place where young people are being prepared for life in a dynamic and rapidly developing society. The research is based on the clinical psychotherapeutic method, in particular, comparison of data about deviant behavior of young people with the criterion behavior of others. The author analyzes what intrapsychic mechanisms and qualities block deviant behavior in similar life situations experienced by young people demonstrating normal patterns of behavior. According to the author, these mechanisms and qualities should be highly regarded by teachers and parents. For the first time in the academic literature the researcher pays attention to the factors and qualities that young people with deviant behavior lack rather than analysis of particular patterns of deviant behavior. Instead the author focuses on intrapsychic mechanisms that should be regarded in the process of raising and teaching young people in order to prepare them for life in a dynamic, changing, unstable world. The author also underlines that the main factor of positive tendencies is the self-preservation instinct that has a systematically important nature. Conclusions: 1) School is not only the place where education is provided, most importantly it is the place where young people are prepared for life in our changing, developing and dynamic world. 2) It is important to support the systematically important factor typical for all living creatures including young people - the selfpreservation instinct and particular displays of this instinct including the positive Self developed in the process of interaction with the surrounding world. 3) It is important not only to live 'here and now' in order to live a full life as Greeks did, but also to think about the future. 4) While exercising our 'free will', it is important to consider moral, ethical, legal, biological, social, physical, educational and other factors and rules in order to be successful in life. 5) Nobody is absolutely happy in this world. Difficulties and failures are experienced by everyone from time to time and it is important to remember that overcoming difficulties help to develop personal traits such as mental stability and persitence. Ability to overcome difficulties helps us to succeed in the future. 6) Life is a kaleidoscope of very different situations, therefore we should not think of difficult situations as life 'dead ends' or lose the value and menaing of life (whether it is a bad exam grade, love failure, etc.). It is important to remember that in a little while a young man or woman will smile when remembering his or her bad grade, and their failure in a love affair will only teach them that the first love is not always the only one, on the contrary, it may teach young men to be more optimistic, to become more attractive and to ignore difficulties as something ephemeral. Very often young people are even happy that they did not bind their life with their first love. Famous composer Shalyapin was not accepted to the conservatory at his first trial, either. 7) Life is the most important value that we have (Schweizer talked about 'reverence for life') and no matter how difficult it may be, it is an interesting, creative and venturesome process.
\end{abstract}

Key words: deviant behavior, psychotrauma, freedom, personality, psychotechnics, human existence, evolutionary approach, self-preservation, instinct, construction of the future.

Е.Н. Князева и С.П. Курдюмов констатируют то, что «человек активно конструирует самого себя как личность в своей жизни, научном и культурном творчестве, в образовании и самообразовании, которое длиться всю жизнь. Человек активно встраивает себя в социум, находит подобающую ему «когнитивную (культурную, политическую и т.п.) нишу», что связано с его адекватной самореализацией» [2]. К сожалению, вопросам активной и конструктивной позиции человека по отношению к самому себе в настоящее время не уделяется должного внимания для решения практических задач, стоящих в обществе.

Вместе с тем нынешняя тенденция такова, что общество всё более и более переходит во всех сфеpax жизни с внешнего, попечительского контроля человека органами власти, который существовал всегда, на внутренний, личностный контроль человека, обладающего ответственностью за свою судьбу и инстинктом социально-психологического самосохранения. Освобождение от внешнего контроля не даёт человеку полной свободы и простора для своеволия, так как в любом случае человек как биологическое и социально-психологическое существо живее в мире, в котором действуют определённые социально-психологические, биологические и иные причинно-следственные связи и закономерности. На этот парадокс индивидуальной свободы обращают внимание Князева и Кудюмов, раскрывая содержание известного высказывания по этому поводу Ж.-Ж. Руссо: «Человек рождается свободным, но повсюду он в оковах».

Сегодня никто не будет отрицать актуальность разработки и внедрения в школьную и вузовскую 


\section{Психотехника}

программу технологии подготовки молодых людей к жизни, воспитания умения ориентироваться в сложных условиях динамично изменяющегося и нестабильного мира, сохранения себя как личности, формирования способности избегать множество поджидающих человека опасностей, выработки позитивного отношения к фундаментальным общечеловеческим ценностям, которые дадут возможность и желание каждому молодому человеку прожить жизнь с достоинством, без опасных отклонений. Крайне важно формирование того личностного стержня, который позволил бы молодому человеку пройти через все испытания, которые готовит ему жизнь, с достоинством и честью, ведь жизнь - это своего рода испытания, а испытания интересны и нередко привлекательны. Сейчас, к сожалению, уделяется внимание преимущественно изучению и профилактике отдельных видов девиантных отклонений, расстройств на примерах их проявлений. Основной девиз профилактики «Просветить - значит предупредить» - не всегда учитывает механизмы формирования и сущность девиаций, отклонений. Сама по себе информация, к сожалению, часто не имеют мотивационной силы в психической сфере человека. Исследования, проведённые психологами, показали, что процент курящих школьников после лекции о вреде курения увеличился, так как лекция только подстегнула юношеский познавательный интерес к курению и их желание подражать взрослым, что важно учитывать в практике образовательной и воспитательной деятельности.

С нашей точки зрения, важно изучать не столько людей с девиантными расстройствами, сколько их образ жизни, внутренние механизмы функционирования их психики, их интрапсихическую сущность, психические возможности тех людей, которые живут в тех же условиях, что и люди с девиантными проявлениями, но которые выстояли, не подверглись влиянию девиантных влияний среды. Изучение того, чем это обусловлено, какие свойства личности и механизмы функционирования психики лежат в основе девиантного поведения, дают таким людям возможность устоять против этих соблазнов. Т.е. нужно изучать тот жизненный «фундамент», который был сформирован с детства и формировался в процессе их жизни, что создавало им своеобразный жизненный стержень, ориентацию на позитивные общечеловеческие ценности, создание своеобразного личностного гироскопа, который обеспечивал их жизненную траекторию, как сейчас говорят «тренд», жизнестойкости. Сформированная внутренняя жизненная опора для самосохранения себя как личности в любых, даже сложных условиях, способность проявлять гибкость ради главного позволяют таким людям прожить жизнь с честью и достоинством.

Для более полного и углублённого понимания сущности и природы человека важно изучить генезис и эволюцию человека. Это может способствовать направлению молодых людей по более адекватному пути и формированию у них стержня, определяющего целесообразный вектор саморазвития их личностей. Иными словами, необходимо формирование основной системообразующей функции. Как показали исследования, этой системообразующей функцией является инстинкт самосохранения. Мудрые люди с древних времён понимали, что достигнуть цели можно, только выйдя за её пределы. Мы с этой целью расширили поиск этой системообразующей функции до изучения функций всего живого и пришли к заключению, что этой системообразующей функцией является механизм самосохранения, самовыживания.

Мы наблюдаем это уже в растительном мире. У вирусов, микробов, фактор самозащиты выражается в их видоизменениях, мутации, с целью стать неуязвимыми к антибиотикам, другим лекарственным средствам. Этот процесс наглядно проявляется при наблюдении вспышек эпидемий гриппа. У пресноводных рефлексом самозащиты и самосохранения является нападение или, напротив, убегание. У живых существ на биологическом уровне - это иммунитет.

Зенон, живший более двух тысяч лет тому назад, говорил о фюзисе, силе природы, вечно побуждающей все вещи расти, а выросшие - совершенствоваться. Платон и Аристотель видели сущность человека в его душе как факторе его активности. Душа есть причина и начало живого тела, проявляется как цель и как сущность одушевлённого тела. Иначе говоря, душа есть причина в смысле сущности, сущность есть причина бытия каждой вещи; у живых существ «быть» означает «жить».

С. Мадди ввёл понятие «Жизнестойкости»как центральной сущности личности, а П. Тиллих фактор «отвага» быть [11].

Д.А. Леонтьев акцентирует внимание на высказанную ещё Гегелем идею о том, как определить сущность личности: «Обстоятельства и мотивы господствуют над человеком лишь в той мере, в какой он сам позволяем им это». Т.е., идёт речь о самодетерминации личности, её автономности. «Личность, - говорит Д.А. Леонтьев, - это не природный объект, это то, что человек в процессе индивидуального развития сам из себя делает... Личность - это глобальная высшая психическая функция прогрессивного овладения собственным 


\section{Психология и психотехника 2(89) • 2016}

поведением и внесения новых высших закономерностей в процессе взаимодействия с миром и саморазвития на основе социального опыта, вычерпываемого из мира, и биологической основы, с которой мы в этот мир приходим» [3]. Речь идёт о том, что Д.А. Леонтьев не отрицает того факта, что сугубо личностное в личности ложится на фундамент конституции человека, тип личности, преломляется и в какой-то мере преформируется.

Э. Бёрн пишет: «Есть, однако, нечто сверх этого - некая сила, побуждающая людей расти, развиваться, становиться лучше. Её можно рассматривать как четвёртую силу личности наряду с Эго, Суперэго и Ид, некая система напряжённости в нормальных условиях непрерывно толкающая живые существа в направлении прогресса... почему человек растёт, почему человеческий род пытается стать лучше, почему животные в процессе эволюции становятся предприимчивее»...

Инстинкт самосохранения как универсальный механизм биологической природы для обеспечения и поддержания выживания на этапе перехода жизни на социально-психологическом уровне трансформировался, перешёл в иные формы и сформировал механизм рефлексии, самого субъекта. Перенос внешних предметов, явлений в свой внутренний мир, повышает возможности человека, эффективность его жизни и деятельности, в том числе и во временном аспекте.

Рефлексия (reflexio - обращение назад) - это внутреннее обращение на самого себя. «Рефлексируя, человек уже не является только существом природы, уже не находится в сфере необходимого» (Гегель) [1]. Рефлексия даёт возможность посмотреть на себя со стороны, отрешиться непосредственно от себя самого. Гегель констатировал тот факт, что человек, чтобы познать себя, должен посмотреть на себя как на другого, а потом этого другого воспринять как самого себя.

Рефлексивное сознание есть способ занять позицию по отношению к самому себе, в том числе и к собственной деятельности. Оно формирует не прямую реакцию человека на своё состояние, мотивы, эмоции (фактор короткой автоматической реакции), а вторичные осмысленные поступки, учитывающие многие факторы, в том числе последствия своих поступков, фактор самосохранения своего «Я», т.е. репутации, контекст ситуации. В целом это есть фактор самосохранения своего «Я» на социально-психологическом уровне.

Фактор, инстинкт самосохранения является стержнем, базисом, необходимым для формирования личности как автономной, самодетерминированной, самодостаточной единицы, дающим возможность, обеспечивающим сохранения себя как человека в условиях непрерывно меняющейся обстановки в микросреде, в обществе, т.е. на социально-психологическом уровне.

Инстинкт самосохранения формирует человека как личность, как социально-психологическую единицу через «Я» как точку отсчёта и «Я» как содержания личности, т.е. те факторы, свойства которые надо сохранять, защищать, поддерживая сохранность постоянно в динамичности окружающей среды. Даже само развитие является фактором самосохранения в меняющихся социально-психологических условиях, в ходе развития личности формируется способность прогнозирования будущих изменений, самозащиты от их возможного негативного влияния через саморазвитие.

Даже не содержание «Я», образно говоря, является гироскопом (стабилизатором) личности, поддерживающей её постоянное направление движения. Именно механизм, инструмент, феномен самосохранения в процессе перехода с биологического уровня на социально-психологический уровень сформировал личность, став её стержнем и содержанием. Рефлексирующий человек выступает субъектом собственной деятельности. Пьер Тейяр де Шарден, французский антрополог и философ, говорил о важности не столько знания, сколько осознания знания о факте наличия и содержания у него знания, т.е. обращал внимание на второй уровень сознания - знание о своих знаниях.

Как констатируется в литературе, «господствующей способностью оказалось не мышление, а выживание». Мышление только обеспечивает выживание, но вопрос в том, насколько хорошо это ему удаётся. Нужно рассматривать организацию жизни не только на уровне прямого знания, элементы которого есть у животных, но и на уровне знания о своих знаниях, присущем только человеку.

Суицид - это крайний фактор проявления краха «Я», его содержания, отсутствие в этой ситуации функционирования важного фактора - инстинкта самосохранения, возможностей его проявления, так как аффективно заблокирована сфера возможного в данной ситуации, механизмы саморегуляции личности. Для профилактики данных тенденций, во-первых, важно всегда сосредоточивать внимание на факторе ситуационности, временности. Во-вторых, например, в случае драмы любовного характера (парень ушёл к другой) важна активная позиция, иметь в своём ресурсе сферу возможного. Стать лучше, душевнее, эротичнее, привлекательнее, прелестнее, так как эти свойства наживные, приобретаемые каждым человеком свойства. Девушка может быть не очень красивой, но прелест- 


\section{Психотехника}

ной быть обязана, так как прелесть прельщает, с ней легко и приятно, что придаёт ей душевную силу, мощь. Во-первых, это может вызвать сожаление у парня, что он её бросил, а, во-вторых, формирование у девушки свойств безразличия, равнодушия, пренебрежения к нему. Всё это усилит чувство сожаления у парня.

Важно уметь смотреть на неудачи, трудности любого характера как на ситуацию формирования жизнестойкости, мужество быть в этом изменяющемся мире. Происходит приобретение опыта, формируется умение проявлять инстинкт самосохранения своего «Я» в трудных жизненных ситуациях, умение преодолевать со временем такие трудности или отстраняться от них, если их преодоление из-за объективных условий невозможно осуществить. Известно, например, что даже великий Ф.И. Шаляпин с первого раза не поступил в консерваторию, тем не менее стал великим.

Фактор формирования субъективности, самодетерминация, самопроизвольность, автономность предполагают свободу личности. Ф. Ницше выделил два вида свободы - позитивную «свободу для» и негативную «свободу от». Для реализации фактора самосохранения важны оба вида свободы: «свобода для» положительного и «свобода от» негативного. Нужно развивать тенденции поведения личности в сфере возможностей, носящие в себе положительные жизнеутверждающие устремления.

Эмоционально высшей ступенью является жизнь человека на психическом, личностном и социальном уровне; свою жизнедеятельность он строит сам, выбирая из окружающего мира, что является миром для меня из огромного мира для всех. Он сам активно формирует свой внутренний мир, направления реализации своего «Я» и осуществления своей жизнедеятельности.

Таким образом, и в науке, и в практической деятельности реализуется подход к человеку как к объекту, именно такой подход до сих пор доминирует, что отражается и в печати, и в научных докладах («мы считаем», «мы думаем»). Необходим иной подход. Воспитывая молодых, помогая взрослым, надо находить подход к ним изнутри их субъективной жизни, вникая в то, что сама этот человек считает, что он чувствует, что он думает, в чём он убеждён и почему он так считает и почему он так чувствует. Ведь главным действующим фактором является сам человек, большая доля произвольности самого человека.

Необходимо учитывать природу и сущность человека, который живёт не только в сфере природного, но и надприродного, т.е. собственно личностного в личности, обладает «жизнестойкостью» как системой установок, убеждений, которые сформированы и развиты в процессе его жизни, отвечает бытию в этом мире, имеет личностной потенциал, опосредованные его внутренним миром вторичные реакции на окружающий мир, обладает свободой выбора в соответствии со своими потребностями. Именно поэтому следует применять другие методологические подходы для изучения его внутреннего мира, его содержательной стороны.

Один из главных, центральных, кардинальных, интегральных, результирующих индикаторов жизнедеятельности человека для самого себя, аккумулирующего совокупную сущность своего бытия, дающего ему ощущение своей жизни, чувство своего бытия, своего «Я», ощущающего ценность жизни самой по себе как факта пребывания в этом мире, ценности эмоциональных переживаний, порождённых взаимодействием содержания «Я» человека с окружающим миром и самим собой, является экзистенция.

Обобщая, можно сказать, что смысл жизни в самой жизни, и бытие, экзистенция - сама жизнь.

Вопрос ценности жизненных проявлений, вещей, ситуаций, смысла жизни, экзистенции в целом с учётом её составляющих форм и сфер требует дальнейшей разработки как общего фактора существования человека и включения её в педагогический, воспитательный процесс с целью формирования психической устойчивости, налаживания полноценной деятельности.

Личность, субъект - это не психические процессы (память, мышление, восприятие и т.д. и т.п.), а их содержательная сторона.

Выпукло, наглядно, контрастно высветил сущность, внутренний мир личности П.Б. Ганнушкин: «Один эпилептоид (или эпитим в рамках нормы наш курсив) может прекрасно вести большое дело, другой эпилептоид - совершить преступление;... один шизоид - всеми любимым поэтом, музыкантом, художником, другой - никому ненужным, невыносимым, бездельником и паразитом».

По существу, человек, в истинном смысле этого слова, не происходит от обезьян, он сам себя формирует в процессе взаимодействия со средой для реализации фактора самосохранения не только в настоящем, но и в перспективе, на будущее, застраховывая себя в перспективе, иначе получился бы не субъект, не личность, а Маугли.

Стержневая сущность человека, его «Я» проявляется в двух факторах. «Я» как точка отсчёта, обособление человека как единицы общества, идентичности самому себе, и «Я» как содержание природы и сущности человека, его индивидуальности, неповторимости. Были примеры, когда 


\section{Психология и психотехника 2(89) • 2016}

однояйцовые близнецы - один был в революцию «красным», другой - «белым». Быть субъектом значит быть творцом своей истории, вершителем своего жизненного пути, осознавать совершённые поступки, нести ответственность за них, иметь навыки самопознания, самопонимания и рефлексии, обладать способностью посмотреть на себя со стороны, обладать вторичной реакцией на воздействие извне, и относиться к своим внутренним импульсам, преломляя их через содержание субстанции субъекта, содержания «Я», своего внутреннего мира.

К сожалению, мы не придаём значения механизмам индукции подсознательного эмоционального состояния между людьми, и не только между ними, но и между взрослыми и детьми. Факторам эмоционального взаимовлияния уделяли внимание в своих трудах Н.К. Михайловский, В.М. Бехтерев.

Сейчас эти феномены рассматриваются с точки зрения центрального понятия динамической психиатрии, по Г. Аммону, - «социальная энергия, т.е. энергия, данная человеку из окружающего его мира, силу, которую люди могут давать друг другу и психическая энергия как идентичность». Социальная энергия может быть конструктивной, негативной, дефицитарной, т.е. социального энергетического голода. Важно чтобы эта социальная энергия была конструктивна, положительна, отсутствие энергетического голода, иначе задержка развития, а отсутствие социальной энергии - Маугли.

Фактор проявления ценимого, ценности бытия, присутствие в жизни, чувство быть само по себе независимо от самочувствия (радость и горе, отсутствие комфорта, страдания) - это явления непреклонные, непоколебимые, не подлежащие сомнениям, разочарованиям, обесценивание этого факта недопустимо. Ценность жизни - аксиома, это тот стержень, который позволяет человеку выживать в любых ситуациях. Чувство ценности жизни, хотя оно часто и не осознаётся, является фундаментом, платформой стойкости человека и носит надвременный, подспудный для всех ситуаций, пожизненный характер. Ведь это свойство всего живого.

Общеизвестное изречение «Жить - значит ежеминутно рождаться» подтверждает это. Человек (ученик) ежеминутно реагирует часто даже автоматически, на подсознательном уровне на сиюминутное воздействие, своё состояние вследствие этого воздействия. Психологу, педагогу важно предполагать его реакцию, его эмоциональное состояние и апеллировать, корректируя эти его реакции в сторону собственных интересов ученика (Я хочу, чтобы ты это знал, укрепил своё реальное честолюбие, самоуважение, а не злился на меня). Что вы и ученик чувствуете, ощущаете при слове жизнь, живое, феномен живого? Осознание природы в сущности этого феномена. Строить на этих ощущениях, представлениях, взаимоотношениях с учеником, как базисном свойстве человека, апеллируя к нему, представляя его как состояние живого. Акцентировать внимание ученика на присутствие у него чувства своего фактора живого, витальности. Умение реагировать в жизни с этим подтекстом этого чувства живого.

Важен анализ образования ценностей для человека в процессе его взаимодействия с обществом, с микросредой с целью инстинкта самосохранения, самозащиты и в этом процессе дальнейшее формирование содержания своего «Я», обогащенного опытом, понимания жизни, её закономерностей и свойств проявления.

Нужно учитывать систему координат формирования ценностей, интересов, сфер деятельности в жизни человека, т.е. то, что даёт ориентиры для поступков и действий человека, что позволяет ему реализовывать свою сущность, развиваться, удовлетворённость своей жизни. И в то же время выявлять то, что играет защитную роль, какие понятия его оберегают, не дают ему сбиться с пути, поддерживают его инстинкт самосохранения, т.е. параметры возможности и личного запрета, что полезно, а что вредно. Нужно открывать в нём жизненные ориентиры, которые позволяет ему быть человеком, не опуститься, не дискредитировать себя. Нужно облегчить ему путь к пониманию свой миссию в жизни, т.е. сущность его бытия и её поддержания.

Полезно при этом учитывать типологию состояний, жизненных установок учеников. Наиболее типичные типы поведения учеников в школе:

1. Беззаботность, отрешенность от учёбы, нет личной вовлечённости в учёбу.

2. Отсутствие сформированного мотива к учёбе, нет понятия представления о ценности учёбы, её роли в жизни учащегося. Жванецкий сказал, что остались одни сообразительные, куда же умные подевались.

Необходимо показывать, что учёба способствует умственному развитию, даёт знания о жизни, окружающем мире, ведь человек есть то, что он знает, умеет, пережил, как накопил жизненный опыт, содержание этого опыта. Формировать у учащихся понятия сферы возможного, показывать наглядно пути выхода из неудачи в учёбе, в частности, проводить определённое и достаточное время в сфере своего внимания определённым темам, предметам, сделать их понятными для себя, естественными и привычными. 


\section{Психотехника}

В школах мало уделяется внимания формированию способности учиться, и педагогам необходимо уделять этому вопросу внимание, углублять, детализировать этот процесс.

Нужно подчёркивать, что человеку позволен выбор линии поведения, действий, но он несвободен в последствиях своей линии поведения, действий. Важно в классе на примерах анализа возможной линии поведения, действий и их последствий показать под углом полезности и вредности упущенных возможностей.

Агрессивность, разрушительность - опасная тенденция человека, часто ведёт к чему-то непоправимому с потерей авторитета, привычных отношений, положения, вызывая впоследствии раскаяние в проявлении агрессивности, разрушительных поступков, деструктивного поведения. Поэтому необходимо культивировать толерантность, терпимость к непривычному, не принятому, чужому, не естественному с пониманием и терпимо относиться к поведению других людей другого уровня проявления культуры, выдержки, терпения, душевная солидность, мудрость.

Решая проявить, сделать какой-то поступок, надо предвидеть его последствия. По этому поводу говорят «человек свободен в своих поступках, но не свободен в их последствиях».

В некоторых случаях аффективно суженного состояния провоцируется оппонентом, который не столько оппонирует, противоречит, возражает в чём-то человеку, сколько преследует цель индуцировать состояние агрессии, направленное к внутреннему, эмоциональному состоянию человека, его сущностного состояния. Происходит проецирование оппонентом своего внутреннего переживания агрессии на внешнюю ситуацию, его энергетические импульсы в виде эмоциональных переживаний не получают разрядки и выливаются в виде внешних агрессивных действий. Эту способность в народе характеризуют как способность доводить других до белого каления. Таким способом нередко жёны доводят мужей, их взвинчивая, внутренне испытывая эмоциональное возбуждение без проявлений в речи. Обусловленность этого феномена в личных комплексах, неудовлетворённость в чём-то, способностью, предуготованность к возмущению даже какими-то другими проблемами на тему вымещения, проекции своих состояний на других, индифферентных проблем.

Нужно формировать, тренировать способность не поддаваться, не воспринимать эмоциональное состояние индуцирующего, его внушающий фактор, а фиксировать внимание на содержании сущности спора, и, наоборот, продуцировать состояние спокойствия, уравновешивания, миролюбия или подтекст уйти из этой ситуации, своим состоянием способствовать его успокоению, не взвинчивать его ещё больше.

Стоит также поднять вопрос на группе о садизме, т.е. типа людей, которые чувствуют полноту, ценность жизни от беспредельной власти над другими людьми, причинять им унижения, страдания. Такое обговаривание способствует в какой-то мере тому, чтобы компенсировать таких людей.

Выражение «иметь царя в голове» означает иметь своеобразную нить, направление, ориентир поведения, своего рода жизненный джи-пи-эс, глонасс, которые оберегают человека от неприятностей, деструктивных действий, вредностей, недозволенных и неприличных поступков. Таким царём в голове, оберегом, путеводительной нитью служит единство чувства ценности жизни и инстинкта самосохранения, которые взаимопорождают, взаимосвязывают друг друга. Чувство ценности жизни порождает, актуализирует инстинкт самосохранения, а инстинкт процесса своей реализации ценности жизни. Ведь то, что не имеет ценности для человека - не порождает мотив к сохранению. Поэтому необходимо в старших классах продолжать укреплять, усиливать на подсознательном и сознательном уровнях чувство ценности жизни.

Как показывают исследования, часто школьники считают ценностью наличие чего-то (магнитофоны, айфоны, планшеты), свои интересы, дела, но не учитывают того, ценностью являются они сами, они не осознают ценность себя, поэтому часто ставят под удар в своих поступках самих себя, своё положение в жизни.

Необходимо акцентировать внимание школьников на чувстве себя, своей жизни, бытия как ценности. Учителям важно прямо им говорить в классе о том, чтобы оны попытались воспроизвести в себе ощущение своего бытия в классе, в школе, понять, как это ценно, значимо, как ценны мы сами по себе для себя, наша жизнь, что мы есть в классе, в школе, запомнить, запечатлеть в себе эти чувства собственной ценности, непреходящей ценности быть в этой жизни.

Наличие априорной, самой по себе ценности жизни, бытия самого по себе как ценности служит гарантом жизни, инстинктом самосохранения, отстранения от всего плохого при крахе составляющей экзистенции, порождённой неудачами, нереализованностью, внешних ценностей, ценностных отношений с другими людьми, т.е. на психосоциальном уровне.

Априорная ценность жизни, бытие само по себе как ценность являются платформой, незы- 


\section{Психология и психотехника 2(89) • 2016}

блемым фундаментом, которые позволяют человеку выстоять в трудностях, перипетиях жизни даже в критических случаях, обеспечивают формирование феномена психической устойчивости. В таких случаях человек не отождествляет себя, свою жизнь в целом со случившимся. Да, он переживает, страдает, но он как ценность, его жизнь как ценность не отождествляется с фактором психотравмы. Иными словами, он отделяет себя как свою сущность и своё функционирование в своей деятельности. Наши исследования людей с психологической устойчивостью показали наличие такого феномена, как свойства личности, субъекта с его свойством рефлексии, способности посмотреть на себя со стороны, на свои действия. Тренировать у учащихся способность посмотреть на себя как на другого, а потом этого другого принять как себя, на что указывал ещё Гегель. Не отождествлять себя, свою сущность с экзаменом, любовной драмой, другими психотравмами, а, наоборот, разотождествлять, т.е. «я» - это «я», а это моё переживание, которое функционально и со временем как обычно теряет актуальность. Даже после плохой отметки на экзамене, ухода любимого человека моя жизнь продолжается, и главное - выстоять, пережить эти трудные времена, посмотреть, что будет потом и нередко в дальнейшем оказывается, что это случившееся даже к лучшему.

Важно усвоение техники их нейролингвистического программирования - «вне кадра» и «в кадре». Школьник наблюдает себя со стороны и в представлении уже обладает необходимыми свойствами (ценность себя самого по себе, своего бытия, независимо от жизненной ситуации, разотождествление себя, своей ценности и переживаемой психотравмы), в разных сценических ситуациях проявляя их, владеет ими, но всё это происходит как бы со стороны. «В кадре» он входит в этот образ, и он уже как действующее лицо «проявляет активность», а не со стороны как наблюдатель как в первом варианте наблюдает свою активность. Эти техники очень важны, так как способствуют укреплению субъективности, самоопределённости, отделению, выделению своего «Я» от реальности, ситуации быть вне ситуации.

Для профилактики таких состояний важно формирование навыков преодоления ситуационно аффективно-суженного сознания, важно формирование в таких случаях установки на целостное восприятие своей жизненной ситуации. И на этом фоне реального положения дел то, что случалось, осознается как малозначимое. Не нужно возводить эту, по сути дела, мимолётную ситуацию на фоне его жизни в ранг сверхценной идеи, напротив, нуж- но разотождествлять себя с ней, низводить её, проводить тренировку на фоне ролевых игр. Целостное восприятие жизненной ситуации является тем фундаментом, на котором держится стабильность человека. На что похож человек, когда он на любое явление жизни реагирует изолированно, без целостного восприятия своей жизни, когда имеет место неадекватная форматизация отдельных событий? Психотерапевт должен его ориентировать, напротив, на то, чтобы предвидеть, предупреждать любые нежелательные последствия своих поступков, предотвращать их, их дезактуализируя.

Необходимо формирование адекватных, истинно значимых явлений, свойств, сфер деятельности, увлечений. Полезно ставить ученикам вопрос: что для них значимо, а что нет. Умение выделять в жизни главное и второстепенное - это умение нужно специально формировать, учить исходить в своих действиях не от возможного в данной ситуации, а от последствий этих действий.

Целесообразно, кроме того, ставить вопрос о том, какие свойства, навыки личности развивают игры на компьютере, планшете, как они помогают в учёбе, а не просто одобрять интерес к ним. Конрад Лоренц, лауреат Нобелевской премии по физиологии, подчеркивал: «Жизнь - это решение проблем». Поэтому важно разбирать с учениками вопрос, какие проблемы они решают и какие проблемы надо решать (учёба, подготовка к жизни, избегание неприятностей, опасностей, поддержание инстинкта самосохранения и т.д. и т.п.).

Важно у учеников не прямо, подсознательно формировать способность иметь мужество жить своей жизнью. У некоторых из них есть стремление к чему-то необычному, сверхвозможному. Но во всём есть предел, и если это стремление уходит в негатив, то его нужно дезактуализировать. У каждого есть «мир для меня», т.е. то, что он из окружающего мира включает в свой мир. Следует разобрать, обговорить с учениками, что в мире для них является ценностями, что они ценят, что составляет ценность их жизни, в том числе ценность быть. Нужно учитывать тот факт, что каждый человек в первую очередь думает о себе, каждый для себя главный, но его стремление удивлять других имеет пределы и является преходящей ценностью. Поэтому важно жить своей жизнью, жить в своём классе, группе, коллективе, городе, улице, деревне, чувствовать характер этой жизни, её непреходящую ценность, её гармонию. Чувствовать процесс удовлетворённости своей жизнью, бытием, экзистенцией и глубину этих переживаний. Важно формировать, тренировать глубину чувства своей жизни в повседневности, чувство значимости своего бытия. Переживания жизни по 


\section{Психотехника}

принципу «здесь и теперь», но с перспективой на будущее - вот что необходимо.

Г. Фолльмер подчеркивал: «Конечно, наш мозг возник не как орган познания, как орган выживания. Но фактически он годится для большего. Мозг делает нас способными строить гипотезы и теории, которые выходят далеко за пределы мезокосма, к которому он определен» [14]. Поэтому важно сформировать у учеников понимание, что мозг возник как орган самосохранения, но с помощью умственной деятельности он развивается.

Подобно тому, как в жизни ребёнку необходимо встречаться с инфекциями гриппа и других подобных болезней, делать прививки, чтобы сформировать защитные механизмы, так и для развития личности ребёнка необходимо встречаться с трудностями и приобретать опыт их преодоления. Ребёнок, который рос вне инфекций, изолированно, рискует попасть в неприятные ситуации. Так и в отношении психотравм, трудностей, препятствий надо приобретать опыт. В силу этого важно, чтобы ученики смотрели на трудности как на жизненные ситуации, их закаляли, формировали способности справляться со своими переживаниями, и при этом у них формировались механизмы компенсации своих притязаний, могущих иметь негативные последствия. Учитывая фактор дезактуализации психотравм в будущем, нужно у учеников формировать умения смотреть на психотравмы в перспективе будущего своего развития, изменения своего положения в ходе взросления.

Важно учитывать, что у человека есть сфера не только необходимого, но и возможного. Нужно формировать навык видеть возможное, возможные пути своего развития, перенестись в своём воображении в перспективное будущее. Как было выше сказано, психотравмы, состояния неудач, фиаско должны стимулировать молодого человека. Готовность к жизни должна включать в себя привычку переживать трудности, испытания, умение делать неактуальной психотравму, изменять смысл воспринимаемого случившегося. Молодой человек должен не винить других, а искать вину в себе, что не учел всего, не изменился. Мишель Монтень в «Опытах» писал, что нас мучают не вещи (явления, ситуации), а наше представление о них.

Молодому человеку стоит посоветовать не отождествлять, не идентифицировать свою значимую жизнь и её смысл только с одной сферой жизнедеятельности. С этой точки зрения мною была разработана технология «Формирование полноценной жизнедеятельности как заключительный этап психотерапевтического процесса $[4 ; 5 ; 6 ; 7 ; 8 ; 9]$.
Нужно тренировать у учеников умения, навыки вдохновлять себя в трудные моменты жизни, понимать, что всё проходит. Не надо отождествлять себя с психотравмой («я страдаю»), надо разотождествлять её со своим «я» («мною пытаются овладеть страдания, но я это смогу пережить и выйти из этого с честью»). Подготавливая учеников к жизни, надо показывать, что жизнь - это испытания и не только приятного характера, но и неприятного и быть готовым к этим факторам жизни и адекватно переживать и то, и другое.

Присутствие во всех моментах жизни чувства бытия, экзистенции, того, что я есть («да, я в настоящее время страдаю, но живу»). Наполеон сказал: «Лучше страдать, чем ничего не чувствовать». Эти слова Наполеона интерпретировать так: «Лучше страдать какое-то время, чем не быть совсем».

Уметь страдать - необходимое для жизни качество. Если бы не было страдания, не было бы и радости. Если есть только одна радость, то жизнь со временем теряет ценность, пропадают ориентиры жизни, и такой человек, а с ним и все общество, деградируют, разрушаются. Пример этому - Римская империя.

Ничего не возводить в ранг абсолюта - вот что советует психотерапевт. Необходимо адаптировать школьников в мыслях, в воображениях на всякий случай, для формирования у них психической устойчивости к трудным, шокирующим, несправедливым ситуациям, сформировать у них умение адекватно реагировать на перспективу жизни в будущем, готовность ко всему. Необходимо формировать внутреннюю готовность к этим негативным, но реальным факторам жизни, тогда возникает бо́льшая гарантия на проявление психической устойчивости, блокировку поспешности, автоматизмов, короткого замыкания в решении проблем, проявления адекватности.

Важно при обсуждении в классе поднять вопрос характера, типа, стиля общения с целью, с одной стороны, дать ученикам понятие о типах, стилях общения с подтекстом критического отношения к своему стилю с последующей его коррекцией, с другой стороны, сформировать у учеников понимание, к каким типам общения относится твой собеседник и в одних случаях избегать общения с ним, в других - воспринимать снисходительно, не раздражаться, в-третьих, игнорировать его эмоционально-волевое воздействие, его попытки индуцировать вас плохим состоянием от него.

Нужно разобрать со школьниками: что вас может шокировать в этой жизни? Что для вас в соответствии с вашим мировоззрением не может случиться? Как, каким образом могут поступить 


\section{Психология и психотехника 2(89) • 2016}

другие люди, что вам кажется невозможным? Расспросить школьников об их представлении на эту тему, как они будут реагировать на это, как они встретят это в реальной жизни. Такая воображаемая адаптация способствует более зрелому типу реакции и делает происшествия менее значимыми.

Необходимо культивирование проявления фактора страха как индикатора инстинкта самосохранения, отнесения событий, явлений к опасным, которые не носят характера очевидного, явного, но могут иметь тяжёлые, а нередко и трагические последствия.

Важную роль в формировании девиантных отклонений в поведении может играть феномен скуки и часто служит почвой их формирования, попадания под влияние ненужных людей, негативных тенденций.

Важно тренировать способность обогащать проявления своей жизни, видеть в повседневности, однообразии жизни её многообразие, своеобразные предвкушения наслаждения, душевность, теплоту, уют, радость, наслаждение покоем, отдыхом. Надо использовать приём налаживания полноценной жизнедеятельности, обогащения своего внутреннего мира чтением художественной классической литературы, где обычно описывается бытие людей, их экзистенция. Возможны, если это целесообразно, исходя из состояния учеников в классе, но без персонификации, дискуссии на следующие темы:

1. Понятие о плохом в понимании учеников. Примеры поведения с подтекстом плохого, неприемлемого. Почему, по мнению учеников, некоторые стремятся быть лидером в плохом? Понятие опасности, липового геройства;

2. Проблема способности быть хорошим, приятным, понятие хорошего, приятного;

3. Не выделяться как самоцель, а развиваться, готовиться к жизни, создавать душевный багаж для жизни в окружающей среде;
4. Понятия о типах взаимодействия с окружающим миром;

5. Формирование приёмов противостояния, ограждения себя от плохого (дежурная фраза в этих случаях для себя - «я что - дурак», «я - не дурак и делать этого не буду», «я в этой ситуации проявляю себя отказом»).

В классе или группе важно проводить разбор, анализ сферы необходимого и сферы возможного на конкретных примерах понятийного аппарата учеников. Каждая жизненная ситуация и проблема в этой ситуации воспринимается человеком с учётом существующего содержания его «я», ранее сформированного во взаимодействии с предыдущими ситуациями, под углом ценностного содержания «я». Оно может накладывать определённый отпечаток, приводя к его трансформации, а может быть и незначимо, тогда этот процесс не затрагивает существующую значимость содержания «я», т.е. становиться индифферентным. Этот механизм, процесс, феномен жизни, формирование индивидуальной сущности человека требует дальнейшего изучения человека, разработки, что способствовало бы более детальному прогнозированию развития человеческой личности.

Итак, задача воспитания - это не только и не столько образование, просвещение, познание законов и свойств окружающего мира, факторов, действующих в нём, но и формирование у человека фундаментальных общечеловеческих свойств, ценностей, личностного стержня, «царя в голове», которые позволили бы ему прожить свою жизнь с достоинством и с честью без раскаяния для себя, без огорчения, без страдания родных и близких и без проблем для общества. Б.М. Теплову принадлежат слова: «...не то, что способности проявляются в деятельности, а то, что они создаются в этой деятельности» [13]. Поэтому важно создавать условия деятельности, нужной для успешной жизни в наше непростое динамическое время.

\section{Список литературы:}

1. Гегель Г.В.Ф. Работы разных лет: в 2 т. М., 1971. Т. 1. С. 23.

2. Князева Е.Н., Курдюмов С.П. Основания синергетики. Человек, конструирующий себя и своё будущее. М., 2014. С. 19.

3. Леонтьев Д.А. Личностный потенциал: структура и диагностика. М.: Смысл, 2011. С. 8.

4. Павлов И.С. Модель трезвенника как цель лечения больных хроническим алкоголизмом // Методическое пособие Центрального ордена Ленина Института усовершенствования врачей. М., 1980. С. 56.

5. Павлов И.С. Формирование социально-психологической устойчивости как фактора первичной профилактики девиантных видов поведения среди детей, подростков и молодёжи. Пермь: Изд. МиГ, 2001. 30 с.

6. Павлов И.С. Психотерапия в практике. M.: Per Se, 2003. 383 с. (Б-ка психотерапии и консультирования); Изд. 2. М.: Рег se, 2004; 3-е изд., перераб. и доп. М.: Per se, 2006. 607 с.

7. Павлов И.С. Психотерапия в практике, технология психотерапевтического процесса. М.: Академический проект, 2012. $511 \mathrm{c}$.

8. Павлов И.С. Подходы к построению психотерапевтического процесса в клинике невротических расстройств и расстройств личности и поведения у взрослых. Методические рекомендации № 2000/132, МЗ РФ. М., 2001. С. 43. 
9. Павлов И.С., Земцова Н.И., Фёдорова С.С. Личная терапия в процессе профессиональной подготовки как способ повышения эффективности психотерапевтов // Научный диалог. 2012. № 11. Психология. Екатеринбург, 2012. С. $109-118$.

10. Пушкин А.С. Собр. соч.: в 10 т. М.: Правда, 1998. Т. 4. С. 143.

11. Тиллих П. Мудрость быть. М., 1995. С. 56.

12. Тейяр де Шарден П. Феномен человека. М., 1987. С. 67.

13. Теплов Б.М. Избранные труды: в 2 т. М., 1986. С. 29.

14. Фолльмер Г. Эволюция и проекция - начало современной теории познания. // Эволюционная эпистемология. Антология / Научн. ред. Е.Н. Князева. М., 2012. С. 231.

15. Швейцер А. Благоговение перед жизнью. М.: Прогресс, 1992. С. 217.

16. Гуревич П.С. Философское мировоззрение // Философия и культура. 2012. № 12. С. 4-5.

\section{References (transliterated):}

1. Gegel' G.V.F. Raboty raznykh let: v 2 t. M., 1971. T. 1. S. 23.

2. Knyazeva E.N., Kurdyumov S.P. Osnovaniya sinergetiki. Chelovek, konstruiruyushchii sebya i svoe budushchee. M., 2014. S. 19.

3. Leont'ev D.A. Lichnostnyi potentsial: struktura i diagnostika. M.: Smysl, 2011. S. 8.

4. Pavlov I.S. Model' trezvennika kak tsel' lecheniya bol'nykh khronicheskim alkogolizmom // Metodicheskoe posobie Tsentral'nogo ordena Lenina Instituta usovershenstvovaniya vrachei. M., 1980. S. 56.

5. Pavlov I.S. Formirovanie sotsial'no-psikhologicheskoi ustoichivosti kak faktora pervichnoi profilaktiki deviantnykh vidov povedeniya sredi detei, podrostkov i molodezhi. Perm': Izd. MiG, 2001. 30 s.

6. Pavlov, I. S. Psikhoterapiya v praktike. M.: Per Se, 2003. 383 s. (B-ka psikhoterapii i konsul'tirovaniya); Izd. 2. M.: Per se, 2004; 3-e izd., pererab. i dop. M.: Per se, 2006. 607 s.

7. Pavlov I.S. Psikhoterapiya v praktike, tekhnologiya psikhoterapevticheskogo protsessa. M.: Akademicheskii proekt, $2012.511 \mathrm{~s}$.

8. Pavlov I.S. Podkhody k postroeniyu psikhoterapevticheskogo protsessa v klinike nevroticheskikh rasstroistv i rasstroistv lichnosti i povedeniya u vzroslykh. Metodicheskie rekomendatsii № 2000/132, MZ RF. M., 2001. S. 43.

9. Pavlov I.S., Zemtsova N.I., Fedorova S.S. Lichnaya terapiya v protsesse professional'noi podgotovki kak sposob povysheniya effektivnosti psikhoterapevtov // Nauchnyi dialog. 2012. № 11. Psikhologiya. Ekaterinburg, 2012. S. 109-118.

10. Pushkin A.S. Sobr. soch.: v 10 t. M.: Pravda, 1998. T. 4. S. 143.

11. Tillikh P. Mudrost' byt', M., 1995. S. 56.

12. Teiyar de Sharden P. Fenomen cheloveka. M., 1987. S. 67.

13. Teplov B.M. Izbrannye trudy: v 2 t. M., 1986. S. 29.

14. Foll'mer G. Evolyutsiya i proektsiya - nachalo sovremennoi teorii poznaniya. // Evolyutsionnaya epistemologiya. Antologiya / Nauchn. red. E.N. Knyazeva. M., 2012. S. 231.

15. Shveitser A. Blagogovenie pered zhizn'yu. M.: Progress, 1992. S. 217.

16. Gurevich P.S. Filosofskoe mirovozzrenie // Filosofiya i kul'tura. 2012. № 12. S. 4-5. 